\title{
The Polish Ethnographic Atlas: Research Achievements and Prospects
}

\author{
AGNIESZKA PIEŃCZAK
}

Institute of Ethnology and Cultural Anthropology, University of Silesia in Katowice agnieszka.pienczak@us.edu.pl

\begin{abstract}
In 1998, the source materials of the Polish Ethnographic Atlas - collected over many decades with the participation of the Institute of History of Material Culture (a unit of the Polish Academy of Sciences) and several leading ethnological centres - were moved to the Cieszyn Branch of the University of Silesia (currently the Faculty of Ethnology and Education). It was then that Z. Kłodnicki, the editor of the PEA, came up with the idea to continue and finish the atlas studies. However, the work on fulfilling the PEA, the biggest project in the history of Polish ethnology, is still going on.

Nowadays, the materials of the Polish Ethnographic Atlas constitute a precious, unique in the national scale, documentary base. For several years, a lively cooperation has taken place between the PEA staff (representing the Faculty of Ethnology and Education of the University of Silesia) and various cultural institutions, government and non-government organizations. The discussed projects are usually aimed at the preservation and protection of the cultural heritage of the Polish village as well as the broadly related promotion actions for activating local communities.

The workers of the Polish Ethnographic Atlas since 2014 have been also implementing the Ministry grant entitled The Polish Ethnographic Atlas - scientific elaboration, electronic database, publication of the sources in the Internet, stage I (scientific supervision: Ph.D. Agnieszka Pieńczak). What is an integral assumption of the discussed project is the scientific elaboration of three electronic catalogues, presenting the PEA resources: 1) field photographs (1955-1971) 2) the questionnaires concerning folk collecting (1948-1952), 3. the published maps (1958-2013). These materials have been selected due to their documentary value. The undertaking has brought about some measurable effects, mostly the special digital platform www.archiwumpae.us.edu.pl. This material database of
\end{abstract}




\begin{abstract}
ethnographic data might become the basis for designing various non-material activities aimed at preserving the cultural heritage of the Polish village.
\end{abstract}

KEY WORDS: ethnology, Polish Ethnographic Atlas, Polish village, protection and preservation of cultural heritage, digitalization

The subject matter of the presented study is associated with Zygmunt Kłodnicki's article published in the international journal Ethnologia Europae Centralis ten years ago (KŁODNICKI 2005). However, a lot have changed in the profile of the scientific research of the Polish Ethnographic Atlas (PEA) conducted unceasingly since the end of the $20^{\text {th }}$ century. In 1998, the source materials concerning the Polish rural culture - collected over many decades with the participation of the Institute of History of Material Culture (a unit of the Polish Academy of Sciences) and several leading ethnological centres - were moved to the Cieszyn Branch of the University of Silesia (currently the Faculty of Ethnology and Education). It was then that Z. Kłodnicki, the editor of the PEA, came up with the idea to continue and finish the atlas studies.

Aided by students, I have completed the research into demonology, folk knowledge and beliefs and neighbour support. In this way, the field studies for the PEA have been finished. With the help of students and doctoral students, the maps and comments on birth customs, rituals and beliefs have been prepared. They are intended for print in the nearest years (KŁODNICKI 2005:100).

However, the work on fulfilling the PEA, the biggest project in the history of Polish ethnology, is still going on.

\title{
The specificity of PEA research work
}

The specificity of PEA research work and the potentialities of applying atlas materials have been largely discussed over the last several years ${ }^{1}$. What should be reminded here is that the research activity of the PEA is based on two mainstays: the documentary one (collecting fieldwork materials, museum and library search) and the interpretative one (elaborating appropriate systematics which take into account various forms and varieties of the

See: e.g. KŁODNICKI 2001a, 2001c, 2005, 2013; PIEŃCZAK 2009, 2010, 2011b, 2011c; DROŻDŻ 2011; PIEŃCZAK, DIAKOWSKA-KOHUT 2013. For a detailed list of earlier works concerning atlas studies, see: KŁODNICKI 2005:102-104.

DOI: 10.1515/eas-2015-0018 C University of SS. Cyril and Methodius in Trnava. All rights reserved. 
investigated phenomena, preparing maps and concluding on the basis of the spatial ethnographic image). The first stage has been already completed - therefore, the Cieszyn Atlas Unit has rich ethnographic archives, the only of such a size in Poland. The collection comprises several thousands of interview questionnaires, surveys, fieldwork photographs and other archival materials, obtained by Polish ethnologists in the second half of the $20^{\text {th }}$ century nearly all over Poland ${ }^{2}$. The second mainstay of the atlas activity concerns the elaboration of the collected source materials in the form of maps and some corresponding commentaries as well as in the form of special electronic catalogues, which will be discussed later. Preparing the maps requires the earlier systematization of cultural phenomena in regard to particular qualities (mainly the function or form, sometimes also the material and technique). Chronology, the frequency of occurrence and dialectal vocabulary are also important (KŁODNICKI 2013:86). What can be frequently seen on maps are more or less regular spatial configurations of the analysed phenomena, which with the application of the ethnogeographic method might become the basis for concluding about the dynamics of cultural changes. Yet, this necessitates both certain research mindfulness as well as a critical approach to the analysed material, which was deservedly focused on by Kazimierz Moszyński - a pioneer of this method in Poland.

What constitutes the basis of the geographic method is the fact - the simplest example is taken here - that with the passing time, the differently lasting phases of a particular artefact, which came into being in a certain point of the Earth, get decomposed in the spatial platform by expanding in different directions. The geographical ranges of all the changeability phases of this artefact hardly ever agree with each other. Taking the simplest example again, it can be observed that the oldest phases usually reach the furthest; the later - slightly nearer; the latest - still nearer from the starting point. Due to this, the chronological order of the phases gets replaced by the spatial one over the centuries. Geographically examining the ranges of phases, an ethnographer or an ethnologist reconstructs the history of a particular artefact (MOSZYŃSKI 1958:105).

The discussed method is successfully applied and developed in the research work of the Cieszyn centre. The results of these studies are presented not only in The Commentaries on the Polish Ethnographic Atlas but also in a few articles dedicated to particular

These works lasted with some breaks from 1948 (questionnaire studies on folk collecting) to the beginning of the 21 st century (supplementary field studies in north-eastern Poland). 
problems $^{3}$. Many of them are provided with another mappings, which enriches the wealth of Polish ethnographic cartography.

\section{The cartographic output of the PEA (1958-2013)}

What is an integral part of the PEA output are the maps presenting cultural diversification of Poland in the spatial aspect. Undoubtedly, one of major atlas achievements is the publishing of 770 maps (prepared by 45 authors), out of which over a half was done over the last several years. Initially, the atlas research was done under Józef Gajek's scientific supervision and this resulted in publishing a sample booklet and six large-format books of the PEA ${ }^{4}$. This wrapped up the first cycle of the presentation of maps on folk collecting, animal farming, agriculture, food, clothes, building and some other artefacts. Since the nineties of the $20^{\text {th }}$ century, the series of The Commentaries on the Polish Ethnographic Atlas has been issued, which constitutes an important text supplement of the maps concerning the spiritual and social culture. ${ }^{5}$

What is worth doing here is showing the scale of the PEA activities over the last fifty years. The diagram of the publishing activity suggests that the number of the maps published by the PEA gradually grew in 1958-1965, showing a slightly falling tendency in the next period (1967-1999). In 2002 the publishing activity increased over 2.5 times in comparison to 1999 , which was followed by a steady decrease in the next years of the $20^{\text {th }}$ century (see Figure 1). However, it should be emphasized that the earlier maps came into being in Wrocław owing to a large team (in 1958-1999 - 12 people on average), which focused entirely on the atlas activity. The maps prepared in Cieszyn have been done by 7 people - either the workers or graduates of the University of Silesia (in 2002-2013 - 2 people on average $)^{6}$. The data also show that in 1967 the biggest number of people took part in preparing maps and that in the next year their number was gradually falling (see Figure 1). In 2007 and 2009 this number reached the indication 1 (authorial elaborations). Still, the melting human potential does not result in a small number of mappings. The remaining unpublished cartograms, originally meant for print in the form of the booklet

\footnotetext{
3 See: e.g. KŁODNICKI 2001b; PIEŃCZAK 2008, 2011a; PIEŃCZAK, DIAKOWSKA 2011; DROŻDŻ, 2007, 2011, 2013; DIAKOWSKA, 2011.

4 GAJEK (ed.), 1964-1981.

513 volumes of the series have been published so far, out of which 7 in Cieszyn (see LEBEDA [PIEŃCZAK] 2002; DROŻDŻ, PIEŃCZAK 2004; PIEŃCZAK 2007; DROŻDŻ 2002, 2009; KŁODNICKI, PIEŃCZAK (eds.) 2010, 2013.

6 In Cieszyn, many dozens of maps prepared by students in B.A. and M.A. theses have come into being.
} 
VII-IX, are in the PEA archives in Cieszyn (see: KŁODNICKI, 2001: 244-254). After earlier verification, some of them have been used ${ }^{7}$. What is planned for the future is the preparation of the next volumes of The Commentaries dedicated to wedding and birth customs, demonology and some other issues ${ }^{8}$.

Figure 1: The relationship between the number of the published PEA maps and number of their authors (1958-2013)

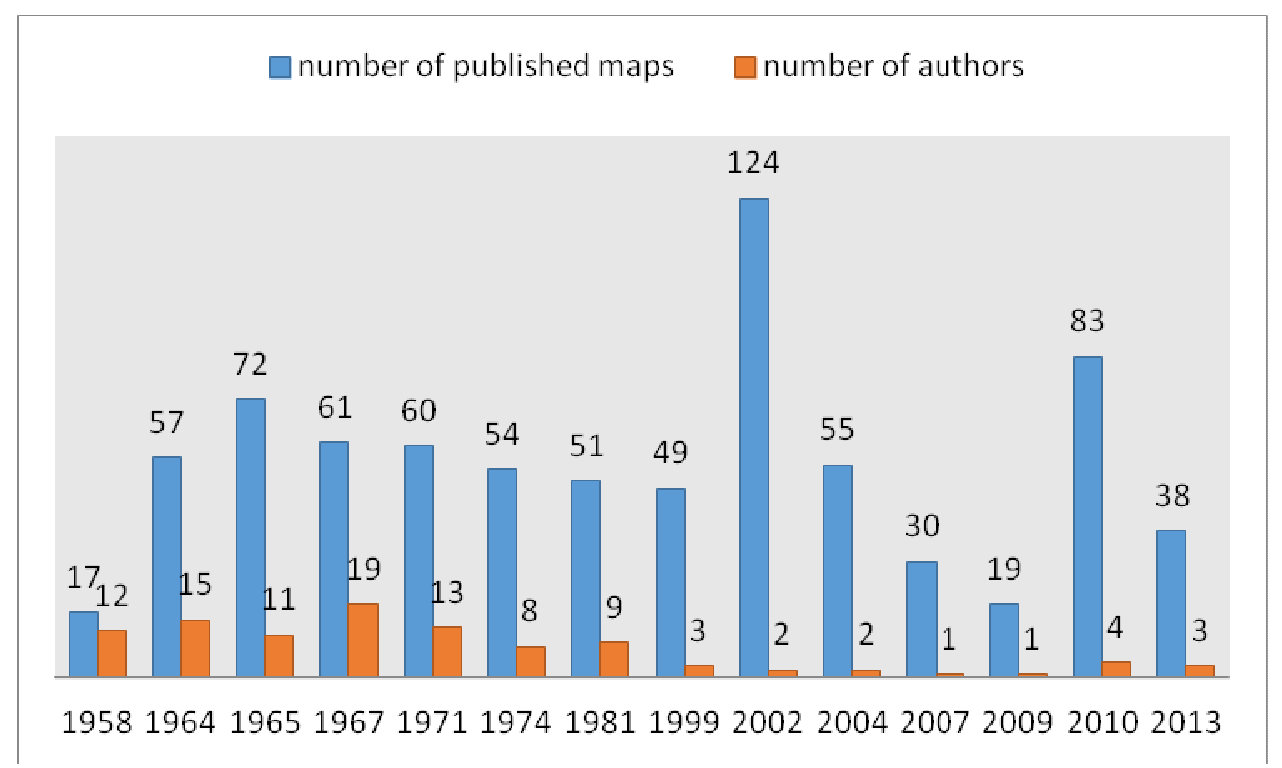

Source: own elaboration

7 In the case of wedding rituals, some of the earlier PEA maps were applied - only the data from the 19th century literaturę were taken into account as well as information from the permanent research network, see: DROŻDŻ, PIEŃCZAK 2004; PIEŃCZAK 2007; DROŻDŻ 2009. Many issues associated with this subject matter have been elaborated anew.

8 The editorial works on The Commentaries have been temporarily suspended due to the implementation of the research project entitled The Polish Ethnographic Atlas - scientific elaboration, electronic database, publication of the sources in the Internet, stage I, (see: the further part of the article).

DOI: 10.1515/eas-2015-0018 C University of SS. Cyril and Methodius in Trnava. All rights reserved. 


\section{Participation in research projects on the protection and preservation of the national heritage}

Nowadays, the materials of the Polish Ethnographic Atlas constitute a precious, unique in the national scale, documentary base. For several years, a lively cooperation has taken place between the PEA staff (representing the Faculty of Ethnology and Education of the University of Silesia) and various cultural institutions, government and non-government organizations. The discussed projects are usually aimed at the preservation and protection of the cultural heritage of the Polish village as well as the broadly related promotion actions for activating local communities (see Table 1). In all the described cases, the PEA materials, obtained directly from the depositaries of local traditions, have become the foundation of different scientific and science popularizing works.

Table 1: Participation of the PEA staff in selected research projects (2010-2015)

\begin{tabular}{|c|c|c|c|c|}
\hline $\begin{array}{l}\text { Research } \\
\text { year }\end{array}$ & Project title & Financial source & $\begin{array}{l}\text { Type of } \\
\text { participation }\end{array}$ & Effects \\
\hline 2010 & $\begin{array}{l}\text { The ways of } \\
\text { preserving the } \\
\text { wooden architecture } \\
\text { of rural territories at } \\
\text { the feet of the Beskids } \\
\text { at the Polish- } \\
\text { Slovakian borderland } \\
\text { contractor } \\
\text { (coordinator: } \\
\text { Fundacja Kamojowa } \\
\text { in Suszec) }\end{array}$ & $\begin{array}{l}\text { Programme of } \\
\text { Transfrontier } \\
\text { Cooperation } \\
\text { Republic of Poland } \\
-\quad \text { Republic of } \\
\text { Slovakia 2007- } \\
2013 \text { - Support for } \\
\text { local initiatives } \\
\text { (microprojects) }\end{array}$ & $\begin{array}{l}\text { contractor: } \\
\text { Agnieszka } \\
\text { Pieńczak }\end{array}$ & $\begin{array}{l}\text { Participation in the } \\
\text { international } \\
\text { conference The } \\
\text { ways of preserving } \\
\text { the wooden } \\
\text { architecture of rural } \\
\text { territories at the feet } \\
\text { of the Beskids at } \\
\text { the Polish- } \\
\text { Slovakian } \\
\text { borderland; popular } \\
\text { science publication } \\
\text { Stan badan } \\
\text { Polskiego Atlasu } \\
\text { Etnograficznego } \\
\text { nad kultura ludową } \\
\text { Suszca } i \text { Kryr (II } \\
\text { potowa XX wieku) } \\
\text { /The state of PEA } \\
\text { research on folk } \\
\text { culture of Suszec } \\
\text { and Kryry (the } 2^{\text {nd }} \\
\text { half of the } 20^{\text {th }} \\
\text { century/ (2010) }\end{array}$ \\
\hline 2012 & $\begin{array}{l}\text { In the land of drowned } \\
\text { spirits and carnival } \\
\text { bear leading - the }\end{array}$ & $\begin{array}{l}\text { Regional } \\
\text { Operational } \\
\text { Programme of the }\end{array}$ & $\begin{array}{l}\text { contractors: } \\
\text { Agnieszka } \\
\text { Pieńczak, }\end{array}$ & $\begin{array}{l}\text { Two popular } \\
\text { science articles: Od } \\
\text { wieńca }\end{array}$ \\
\hline
\end{tabular}


The Polish Ethnographic Atlas: Research Achievements and Prospects

\begin{tabular}{|c|c|c|c|c|}
\hline & $\begin{array}{l}\text { promotion of Silesian } \\
\text { folk culture - the case } \\
\text { of customs, rituals } \\
\text { and legends from } \\
\text { Gliwice County } \\
\text { (coordinator: County } \\
\text { Office in Gliwice) }\end{array}$ & $\begin{array}{l}\text { Silesian } \\
\text { Voivodeship for } \\
2007-2013\end{array}$ & $\begin{array}{l}\text { ethnology } \\
\text { students of the } \\
\text { University of } \\
\text { Silesia }\end{array}$ & $\begin{array}{l}\text { adwentowego do } \\
\text { dożynkowego czyli } \\
\text { tradycje, zwyczaje i } \\
\text { obrzedy powiatu } \\
\text { gliwickiego /From } \\
\text { the advent to } \\
\text { harvest wreath - } \\
\text { the traditions, } \\
\text { customs and rituals } \\
\text { of Gliwice County/ } \\
\text { (2012); O dioble } \\
\text { złośliwym i utopku } \\
\text { życzliwym czyli } \\
\text { legendy i wierzenia } \\
\text { powiatu gliwickiego } \\
\text { /On a mischievous } \\
\text { devil and a nice } \\
\text { drowned spirit - } \\
\text { legends and beliefs } \\
\text { of Gliwice County/ } \\
\text { (2012) }\end{array}$ \\
\hline $2012-2013$ & $\begin{array}{l}\text { Atlas of the non- } \\
\text { material cultural } \\
\text { heritage of rural } \\
\text { Greater Poland } \\
\text { (coordinator: } \\
\text { nationam Museum of } \\
\text { Agriculture and Agro- } \\
\text { Food-Processing } \\
\text { Industry in Szreniawa) }\end{array}$ & $\begin{array}{l}\text { National } \\
\text { Programme for the } \\
\text { Development of } \\
\text { Humanities } \\
\text { (Ministry of Science } \\
\text { and Higher } \\
\text { Education) }\end{array}$ & $\begin{array}{l}\text { contractors: UŚ. } \\
\text { Zygmunt } \\
\text { Kłodnicki, Edyta } \\
\text { Diakowska- } \\
\text { Kohut }\end{array}$ & $\begin{array}{l}\text { participation in the } \\
\text { Scientific Board of } \\
\text { the project, } \\
\text { providing opinions, } \\
\text { reviewing, expert } \\
\text { supervision of the } \\
\text { course of scientific } \\
\text { inquiries } \\
\text { Kłodnicki), scientific } \\
\text { inquiry into PEA } \\
\text { materials } \\
\text { concerning a few } \\
\text { Greater Poland } \\
\text { counties (E. } \\
\text { Diakowska-Kohut) }\end{array}$ \\
\hline 2013-2015 & $\begin{array}{l}\text { Atlas of Polish folk } \\
\text { costumes: } \\
\text { continuation } \\
\text { publishing works, } \\
\text { conducting field } \\
\text { studies and source } \\
\text { inquiries as well as } \\
\text { digitalization of source } \\
\text { materials and sharing } \\
\text { them in the Internet }\end{array}$ & $\begin{array}{l}\text { National } \\
\text { Programme for the } \\
\text { Development of } \\
\text { Humanities } \\
\text { (Ministry of Science } \\
\text { and Higher } \\
\text { Education) }\end{array}$ & $\begin{array}{l}\text { contractor: Anna } \\
\text { Drożdż }\end{array}$ & $\begin{array}{lr}\text { scientific } & \text { inquiry } \\
\text { into PEA } & \text { sources } \\
\text { concerning } & \text { folk } \\
\text { costumes } & \end{array}$ \\
\hline
\end{tabular}




\begin{tabular}{|l|l|l|l|l|}
\hline & $\begin{array}{l}\text { (coordinator: Anna } \\
\text { Brzezińska) }\end{array}$ & & \\
\hline 2015 & $\begin{array}{l}\text { The year of } \\
\text { household farming in } \\
\text { the Pszczyna region } \\
\text { (coordinator: Town } \\
\text { Museum in Pszczyna) }\end{array}$ & $\begin{array}{l}\text { Cultural heritage - } \\
\text { Folk and traditional } \\
\text { culture (Ministry of } \\
\text { Culture and Heritage) }\end{array}$ & $\begin{array}{l}\text { contractors: } \\
\text { Agnieszka } \\
\text { Pieńczak, Edyta } \\
\text { Diakowska- } \\
\text { Kohut }\end{array}$ & $\begin{array}{l}\text { Sharing } \\
\text { materials } \\
\text { concerning } \\
\text { household farming } \\
\text { in the villages: Kryry } \\
\text { and Suszec }\end{array}$ \\
\hline
\end{tabular}

\section{Digitalization and sharing of the PEA collections - the research status quo}

The workers of the Polish Ethnographic Atlas have not only taken part in outer projects but since 2014 have been also implementing the Ministry grant entitled The Polish Ethnographic Atlas - scientific elaboration, electronic database, publication of the sources in the Internet, stage I, within the National Programme for the Development of Humanities (scientific supervision: Agnieszka Pieńczak). The University of Silesia along with the Institute of Anthropology (a project partner) have been granted some substantial funds for scientific elaboration and digitalization of the atlas collections (547878000 PLN, which equals about 127413000 Euro). The major aim of this undertaking is starting long-term research into enriching the cultural and national heritage with the unique ethnographic documentation of several recent decades. This will become possible due to scientific elaboration of the PEA archives into a coherent and synthetic digital collection. These materials are unique sources concerning the history of rural Poland as, contrary to other ethnographic studies, they thematically comprise the whole Poland, which allows for highly developed scientific analyses of cultural diversification of rural areas. What seems of particular significance here is the protection and preservation of the cultural heritage of the Polish village by sharing the PEA materials with a wide group of recipients. These activities seem of due significance also in the context of implementing the resolutions of the UNESCO convention on the protection of the non-material cultural heritage, which Poland ratified in $2003^{9}$.
For the full text of the convention, see: http://niematerialne.nid.pl/Konwencja_UNESCO/Tekst\%20Konwencji\%200\%20ochronie\%20dzie dzictwa\%20niematerialnego/, /accessed: 18.10.2015/. 
What is an integral assumption of the discussed project is the scientific elaboration of three electronic catalogues, presenting the PEA resources: 1) field photographs (1955-1971) 2) the questionnaires concerning folk collecting (1948-1952), 3) the published maps (19582013). These materials have been selected due to their documentary value. The undertaking has brought about some measurable effects, mostly the special digital platform www.archiwumpae.us.edu.pl, which is aimed at cataloguing the collections and at the digitalization workshop of the Polish Ethnographic Atlas (prepared and equipped owing to the support from the Ministry of Science and Higher Education and the Faculty of Ethnology and Education in Cieszyn of the University of Silesia).

During several months of the project implementation, some preliminary works have been done for conservation and itemization of the collections. The digitalization of the published atlas maps and many thousands of black and white field photographs is winding down as well (Figure 2).

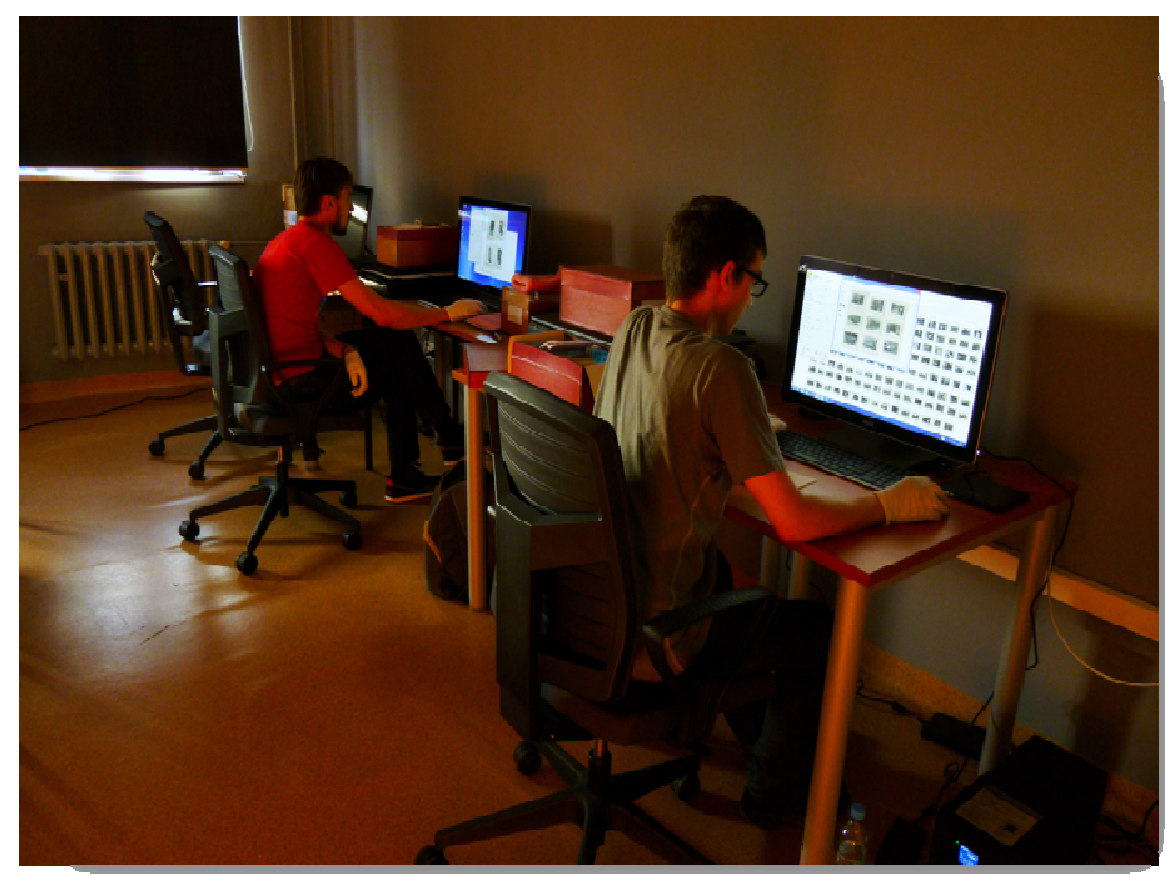

Figure 2: Scanning atlas photographs. Photo: A. Pieńczak. Cieszyn, $13^{\text {th }}$ May, 2015 
A part of the map collection has been subjected to complex digital edition in the Galeneo programme ${ }^{10}$ and the laborious and time consuming research activities have started with the aim of creating a photographic catalogue (see Figure 3 ). ${ }^{11}$ In this case as well it was necessary to prepare the collection for scanning earlier - this required securing the archives, attributing new inventory numbers, verifying erroneous spelling of place names or the existing signatures. It is estimated that the PEA Unit in Cieszyn has 12555 inventory cards with photographs coming from 439 villages in Poland. They constitute a unique ethnographic documentation, which presents some elements of everyday life of rural communities all over the country, including the western and northern territories, subjected to particular migration movements after World War II ${ }^{12}$. Most frequently, the photographs ${ }^{13}$ show agricultural tools, building, means of transport, interior equipment, clothing elements, graveyard architecture and many other artefacts, some of which already belong to the past. $^{14}$

It comprises a metadata Dublin Core set, which consists of 14 elements and is enriched with detailed labels, electronic files and the system of geolocalization of an object.

11 The research is conducted by the scientific staff of the Faculty of Ethnology and Education of the University of Silesia (Cieszyn), supported by the representatives of the Polish Institute of Anthropology (Warsaw), the Institute of Archaeology and Ethnology of the Polish Academy of Sciences (Warsaw) and the Polish association for Folk Studies (Wrocław). There are 10 participants in the project, including 4 main contractors (Agnieszka Pieńczak, Zygmunt Kłodnicki, Joanna Koźmińska, Edyta Diakowska-Kohut). For the detailed information concerning the members of the research team, see: http://www.archiwumpae.us.edu.pl/exhibits/show/uczestnicyprojektu--polski-at, (accessed: 18.10.2015).

12 An outflow of autochthonous population and the settlement of the Polish population from different parts of the country, which largely included the population coming from the eastern territories lost in favour of the Soviet republics of Ukraine, Belarus and Lithuania.

13 An outflow of autochthonous population and the settlement of the Polish population from different parts of the country, which largely included the population coming from the eastern territories lost in favour of the Soviet republics of Ukraine, Belarus and Lithuania.

14 The discussed collections will be successively shared in the Internet, depending on the possibility of obtaining the authors' (or their heirs') consents for publication. 
Figure 3: Presentation of the PEA photographic catalogue in the Galeneo programme (an object from the village of Trzebiszewo) (source: http://www.archiwumpae.us.edu.pl/items/show/1170, screenshot, accessed: 18.10.2015)

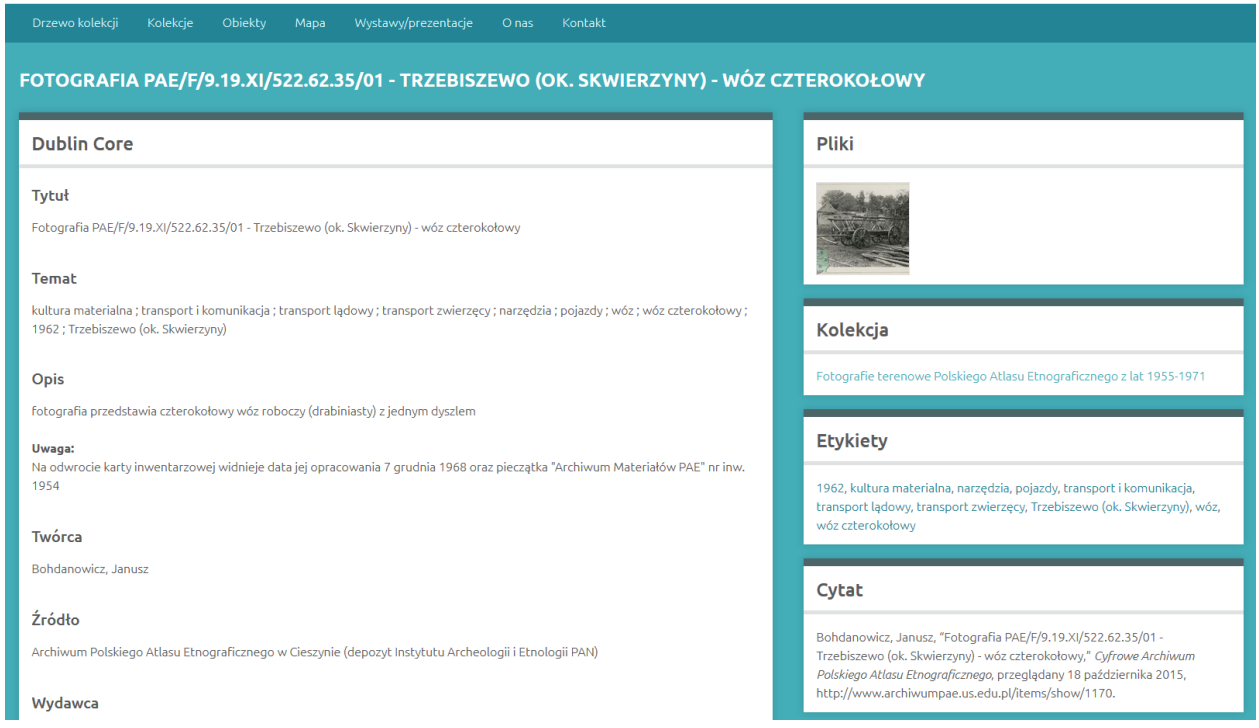

What has also been initiated is the digitalization of nearly 3000 questionnaires with herbaria, which is the oldest collection of atlas data (1948-1952). As in the previous case, at first specialist conservation of the objects took place and then scientific verification was carried out. Currently the herbaria are being photographed and graphically processed.

\section{Developmental prospects}

The sources of the Cieszyn Unit of the PEA are not broadly known in Central European ethnology, therefore converting them into a modern digital form seems by all means useful. What will come into being owing to the efforts of the PEA Unit in Cieszyn is an innovative database, which is valuable not only because of its organization and contents but mainly because of its accessibility. This material database of ethnographic data might become the basis for designing various non-material activities aimed at preserving the cultural heritage of the Polish village. Our major aim has always been the popularization of the rich sources of the Polish Ethnographic Atlas in the scientific and non-scientific environment. This, however, requires many years of research work.

DOI: 10.1515/eas-2015-0018 C University of SS. Cyril and Methodius in Trnava. All rights reserved. 


\section{Bibliography}

DIAKOWSKA E. (2011): Obca kobieta, jako zwiastun śmierci. In. Zeszyty Wiejskie 16, pp.168-177.

DROŻDŻ A. (2002): Pomoc wzajemna. Współdziałanie społeczne i pomoc sąsiedzka. „Komentarze do Polskiego Atlasu Etnograficznego”. V. 7. Zygmunt Kłodnicki (ed.). Wrocław - Cieszyn: Polskie Towarzystwo Ludoznawcze - Uniwersytet Śląski Fila w Cieszynie.

DROŻDŻ A. (2009): Zwyczaje i obrzędy weselne. V. 8. Part III. Współdziałanie społeczności wiejskiej podczas obrzędu weselnego (druga połowa XIX wieku i XX wiek). „Komentarze do Polskiego Atlasu Etnograficznego”. Zygmunt Kłodnicki (ed.). Wrocław - Cieszyn: Polskie Towarzystwo Ludoznawcze - Uniwersytet Śląski Uniwersytet Wrocławski.

DROŻDŻ A. (2011): Possibilities of using ethnographic maps in the study of the process of change in traditional culture in Poland - a case study of the expansion and disappearance of cradles. In. Ethnologia Europae Centralis 10, pp. 29-42.

DROŻDŻ A. (2013): Kołysanie diabła ... - zwyczaje wierzeniowe jako przykład niematerialnego dziedzictwa kulturowego. In: Nauka 1, pp. 129-148.

DROŻDŻ A., PIEŃCZAK A. (2004): Zwyczaje i obrzędy weselne. V. 8. Part I. Od zalotów do ślubu cywilnego. „Komentarze do Polskiego Atlasu Etnograficznego”. Zygmunt Kłodnicki (ed.). Wrocław - Cieszyn: Polskie Towarzystwo Ludoznawcze Uniwersytet Śląski Fila w Cieszynie.

GAJEK J. (ed.), 1964-1981: Polski Atlas Etnograficzny. V. I, maps 1-57 (1964), v. II, maps 58-129 (1965), v. III, maps 130-190 (1967), v. IV, maps 191-250 (1971), v. V, maps 251-304 (1974), v. VI, maps 305-355 (1981). Warszawa: Instytut Historii Kultury Materialnej PAN.

KŁODNICKI Z. (2001a): Etnograficzne atlasy krajów środkowej Europy (Możliwości studiów porównawczych). In. Ol'ga Danglová, Rastislava Stoličná. (eds.): Etnológia a kultúrne dedičstvo. Bratislava: Veda, pp. 56-66.

KŁODNICKI Z. (2001b): Metoda geograficzna i retrogresywna w badaniach nad genezą tradycyjnej kultury. In. Irena Bukowska-Floreńska (ed.). Miejsca znaczące i wartości symboliczne. „Studia Etnologiczne i Antropologiczne”. V. 5. Katowice: Wydawnictwo Uniwersytetu Śląskiego, pp. 153-166.

KŁODNICKI Z. (2001c): Polski atlas etnograficzny - historia, stan obecny i perspektywy. In. Lud 85, pp. 239-275. 
KŁODNICKI Z. (2005): Polski atlas etnograficzny - stan prac. In. Ethnologia Europae Centralis 7, pp. 100-105.

KŁODNICKI Z. (2013): Miejsce Polskiego Atlasu Etnograficznego w etnologii Polski i Europy. In. Jacek Schmidt (ed.): Regiony etnografii. Szkice dedykowane Profesorowi Andrzejowi Brenczowi w 70. rocznice urodzin. Poznań: Wydawnictwo Nauka i Innowacje, pp. 83-105.

KŁODNICKI Z., PIEŃCZAK A., ed. (2010): Zwyczaje, obrzędy $i$ wierzenia narodzinowe. V. 9. Part I. Zwyczaje, obrzędy $i$ wierzenia związane z narodzinami $i$ wychowaniem dziecka. „Komentarze do Polskiego Atlasu Etnograficznego”. Wrocław Cieszyn: Polskie Towarzystwo Ludoznawcze - Uniwersytet Śląski - Uniwersytet Wrocławski.

KŁODNICKI Z., PIEŃCZAK A., ed. (2013): Zwyczaje, obrzędy $i$ wierzenia narodzinowe. V. 9. Part II. Zwyczaje, obrzędy $i$ wierzenia związane $z$ matką $i$ dzieckiem. „Komentarze do Polskiego Atlasu Etnograficznego”. Wrocław - Cieszyn: Polskie Towarzystwo Ludoznawcze - Uniwersytet Śląski - Uniwersytet Wrocławski.

LEBEDA A. [PIEŃCZAK] (2002): Wiedza i wierzenia ludowe. „Komentarze do Polskiego Atlasu Etnograficznego". V. 6. Zygmunt Kłodnicki (ed.). Wrocław - Cieszyn: Polskie Towarzystwo Ludoznawcze - Uniwersytet Śląski Fila w Cieszynie.

MOSZYŃSKI K. (1958): Człowiek. Wstęp do etnografii powszechnej $i$ etnologii. Wrocław - Kraków - Warszawa: Zakład Narodowy im. Ossolińskich - Wydawnictwo Polskiej Akademii Nauk.

PIEŃCZAK A. (2007): Zwyczaje i obrzędy weselne. V. 8. Part. II. Rola i znaczenie swata w kojarzeniu małżeństw. „Komentarze do Polskiego Atlasu Etnograficznego”. Zygmunt Kłodnicki (ed.). Cieszyn - Wrocław: Polskie Towarzystwo Ludoznawcze Uniwersytet Śląski - Uniwersytet Wrocławski.

PIEŃCZAK A. (2008): Sposoby rozpoznawania domniemanych czarownic (w świetle badań Polskiego Atlasu Etnograficznego). In. Lud 92, pp. 215-233.

PIEŃCZAK A. (2009): Dorobek Pracowni Polskiego Atlasu Etnograficznego w Cieszynie. In. Twórczość Ludowa 24 (3-4), pp. 39-43.

PIEŃCZAK A. (2010): Stan badań Polskiego Atlasu Etnograficznego nad obrzędowością narodzinową. In. Teresa Smolińska (ed.). Między kulturą ludową a masową: historia, teraźniejszość i perspektywy badań. Kraków - Opole: Wydawnictwo <scriptum>, pp. s. 121-134.

PIEŃCZAK A. (2011a): Food in the life of a pregnant woman - an analysis of the studies for the Polish Ethnographic Atlas. In. Halina Rusek (ed.): Dilemnas of old and contemporary culture in ethnograghical and anthropological discourse. „Bibliotheca 
Ethnologiae Europae Centralis". V. 3. Cieszyn - Katowice: Offsetdruk i media, pp. 146154.

PIEŃCZAK A. (2011b): Metoda etnogeograficzna w badaniach atlasowych ośrodka wrocławskiego i cieszyńskiego - kontynuacja i zmiana. In. Zeszyty Wiejskie 16, pp. 154-167.

PIEŃCZAK A. (2011c): Specyfika materiałów źródłowych Polskiego atlasu etnograficznego. In. Halina Rusek, Agnieszka Pieńczak (eds.): Etnologiczne $i$ antropologiczne obrazy świata - konteksty $i$ interpretacje. Prace ofiarowane Profesorowi Zygmuntowi Kłodnickiemu w 70. rocznicę urodzin. Cieszyn - Katowice, pp. 41-61.

PIEŃCZAK A. (2011d): Żywotność praktyk magicznych na przykładzie sposobów ochrony dzieci przed urokiem (przygotowano z materiałów „Polskiego Atlasu Etnograficznego”). In. Irena Bukowska-Floreńska, Grzegorz Odoj (eds.): Etnologia na granicy. Dorobek ośrodka etnologicznego UŚ. „Studia Etnologiczne i Antropologiczne”. V. 11. Katowice: Wydawnictwo Uniwersytetu Śląskiego, pp. 231-243.

PIEŃCZAK A., DIAKOWSKA E. (2011): Magia Alkmeny w polskiej obrzędowości narodzinowej i pogrzebowej (w świetle badań Polskiego atlasu etnograficznego). In. Ethnologia Europae Centralis 10, pp. 43-54.

PIEŃCZAK A., DIAKOWSKA-KOHUT E. (2013): Polski Atlas Etnograficzny - dawne i współczesne badania dziedzictwa kulturowego wsi polskiej. In. Ethnologia Europae Centralis 11, pp. 63-69. 